\title{
STRENGTHENING CATFISH EMPOWERMENT GROUP IN LOBANG VILLAGE, LIMPUNG DISTRICT, BATANG REGENCY
}

\author{
${ }^{1}$ Avi Budi Setiawan, ${ }^{2}$ P Eko Prasetyo, ${ }^{3}$ Andryan Setyadharma, ${ }^{4}$ Dwi Rahmayani, ${ }^{5}$ Dyah Maya Nihayah \\ 1,2,3,4,5 Universitas Negeri Semarang
}

\section{ARTICLE INFO \\ Article History: \\ Received January, 14, 2021 \\ Accepted June, 17, 2021 \\ Available June, 302021}

\section{Keywords: \\ Catfish, \\ Empowerment, \\ Limpung}

\begin{abstract}
Tujuan dari pembuatan laporan ini adalah untuk memberikan gambaran mengenai kemajuan pelaksanaan penguatan kelompok pemberdayaan lele di desa Lobang Kecamatan Limpung Kabupaten Batang dimana sebagian besar penduduk bermata pencaharian sebagai petani dan kegiatan ini diperlukan agar kelompok tani dapat mengembangkan usahanya tidak hanya pertanian saja, serta sebagai bentuk pertanggungjawaban peneliti kepada pihak-pihak yang terkait dalam pelaksanaan pengabdian, bahwa kegiatan pengabdian tersebut telah dilaksanakan. Sedangkan tujuan dari kegiatan penguatan kelompok pemberdayaan lele untuk meningkatkan wawasan dan pengetahuan terhadap masalah manajemen produksi maupun jaringan pemasaran budidaya lele kepada anggota Kelompok Tani, meningkatkan pemberdayaan masyarakat melalui pembentukan komunitas atau kelompok usaha yang terdiri dari anggota Kelompok Tani, dan mendorong minat anggota Kelompok Tani Desa Lobang untuk memulai usaha budidaya ikan lele guna meningkatkan suplai produksi ikan lele di Kabupaten Batang. Kegiatan pengabdian diawali dengan kegiatan Focus Group Discussion (FGD) tentang Pemberdayaan masyarakat melalui pembentukan komunitas atau kelompok usaha yang terdiri dari Kelompok Tani.
\end{abstract}

The purpose of this report is to provide an overview of the progress of the implementation of the strengthening of catfish empowerment groups in the village of Lobang Limpung Subdistrict Batang where most of the population has a livelihood as farmers and this activity is necessary so that farmer groups can develop their business not only agriculture alone, as well as a form of accountability of researchers to the parties concerned in the implementation of devotion, that the devotional activities have been carried out. While the purpose of the strengthening activities of catfish empowerment groups to increase insights and knowledge on production management problems and marketing networks of catfish cultivation to members of the Farmer Group, increase community empowerment through the formation of communities or business groups consisting of members of the Farmer Group, and encourage the interest of members of the Farmer Group Lobang Village to start a catfish farming business to increase the supply of catfish production in District Batang. The service activity begins with Focus Group Discussion (FGD) on Community Empowerment through the formation of a community or business group consisting of Farmer Groups.

Address: L Building, Campus Sekaran, Gunungpati, Semarang, Indonesia, 50229

Correspondent Address:

Universitas Negeri Semarang

Email: avibs@mail.unnes.ac.id 


\section{INTRODUCTION}

Agricultural institutions are structured and patterned norms or habits and are practiced continuously to meet the needs of community members who are closely related to the livelihoods of rural agriculture. In the life of the farmer community, the position and institutional function of farmers is part of the social structure that facilitates social interaction or social interplay in a community. Institutional farmers also have a strategic point (entry point) in driving agribusiness systems in the countryside. Therefore, all resources in the countryside need to be directed / prioritized in order to improve the professionalism and bargaining position of farmers (farmer groups).

The institutional role in building and developing the agricultural sector in Indonesia is especially seen in the agricultural activities of food crops, especially rice. At the national macro level, the role of agricultural development institutions is very prominent in programs and projects of intensification and increase of food production. Agricultural development activities are poured in the form of programs and projects by building coercive institutions (forced institutions), such as Padi Sentra, Mass Demonstration (Demas), Mass Guidance (Bimas), Bimas Gotong Royong, Village Unit Business Entity (BUUD), Village Unit Cooperative (KUD), Insus, and Supra Insus.

Batang regency is one of 35 districts / cities in Central Java Province which includes 15 (fifteen) sub districts and consists of 239 villages and 9 villages. Almost $80 \%$ of the population in Batang Regency has a livelihood in agriculture. In addition, the Department of Marine Fisheries and Livestock (Dislutkanak) Batang District encourages fisheries businesses to increase the volume of catfish production, this is driven by the increasing demand for catfish consumption. Batang Regency Government, continues to boost the production of fish. Catfish production in the region in 2018 has reached 20 tons. The number increased dramatically compared to the previous year which was only able to produce catfish as much as 12 tons. Compared to the previous year catfish production has increased significantly, at least can meet the needs of local demand in Batang Regency.

When viewed from the balance sheet of high consumption demand, the market opportunities for catfish cultivation are still wide open. While one of the catfish cultivation actors, based on the observations of researchers, demand in the pantura area of Central Java increased to 1 million heads per month. But farmers are only able to harvest an average of about 600 thousand heads because of the lack of catfish entrepreneurs. According to Dimyati (2006), the problems that are still attached to the figure of farmers and institutional farmers in Indonesia are: (1) There is still a lack of knowledge and knowledge of farmers on production management and network marketing issues. (2) Not yet fully involved farmers in agribusiness activities. Farmers' activities are still focused on farm activities. (3) The role and institutional function of farmers as a container of farmer organizations has not been optimally run.

To overcome the above problems, it is necessary to make efforts to develop, empower, and strengthen farmers' institutions (such as: farmer groups, labor institutions, input providers, output institutions, extension institutions, and capital institutions) and is expected to protect farmers' bargaining positions. Protection measures as a side to these farmers, both as producers and connoisseurs of their farming hard work is mainly manifested through a decent level of output prices and benefit farmers.

Thus, the strengthening and institutional empowerment is also to produce the achievement of sustainability and sustainability of SDA's support capacity and various efforts to support and support the life activities of agricultural development in the countryside. The village itself as a village that is geographically located is somewhat remote from other villages the main problems faced by the villagers are transportation, economic and educational problems. an agricultural institution is needed in the receipt of funds for catfish empowerment. Therefore, researchers are interested in researching empowerment in catfish farmers in Lobang Village, Limpung District, Batang Regency.

Based on the description that has been described earlier, in order to encourage the government's goal to improve the achievement of sustainability and sustainability of SDA's support capacity and various efforts to support and support agricultural development life activities in the countryside, community service was made with the title "Strengthening Catfish Empowerment Group in Lobang Village, Limpung District, Batang Regency". Through this devotion, the hope is that after this training is done, participants are interested to learn more about catfish empowerment. Finally, the economic independence of Indonesian people can also be improved in the future. The fundamental problems experienced by community groups in Lobang Village, Limpung District, Batang, include: (1) Empowerment of community groups has not been optimal. (2) Utilization of land potential and Human Resources is still limited.

\section{METHOD}

This service program will be implemented through the following stages of activities:

1. Community empowerment through the establishment of a community or business group 
consisting of Farmer Groups Implementation Methods: Focus Group Discussion (FGD).

The initial process that will be done is to hold a Focus Group Discussion (FGD) using a participatory approach. This approach is used so that group members understand about the 3 principles of business groups to be formed, namely openness, trust, and togetherness. Through FGD will also grow a more harmonious relationship and can be used as a medium of creativity development. The hope of this process is the emergence of a spirit of togetherness and social solidarity, the emergence of will and selfreliance so that each member of the group has socioeconomic responsibility towards themselves, family and society. The establishment of Farmer Groups is directed to the cultivation of catfish.

2. Catfish Farming Training

Implementation Method : Counseling, Training and Practice

This activity begins with gathering people, especially farmer groups to be given understanding or given counseling on how to cultivate catfish. Then carried out training and practice of the cultivation process. After that will be conducted counseling again on how business management and marketing of the results of his business.

The target audience that needs to be involved in community service activities, and can disseminate the results of activities to other target audience members is the farmer group of Lobang Village, Limpung District, Batang Regency.

A village whose status as one of the villages that has the potential of cultivation. Lobang Village, Limpung Subdistrict, Batangn Regency, actually needs touch and support from related parties. So it is felt that efforts are needed to promote the strengthening of catfish empowerment groups in the village of limpung subdistrict of batang district. The activity was run with lancer and followed by farmer group of Lobang Village. Where at this time the fish has grown large and it is almost the harvest time of catfish. And the plan in the future is to redo the catfish seedlings from the proceeds of catfish sales revenue and can add to the catfish farming pond. The assessment of the success index of this community service program is:

a. The number of people participating in the program of counseling, training, practice and mentoring.
b. Technical mastery in the cultivation process.
c. Sustainability of the program

\section{RESULTS AND DISCUSSIONS}

The devotion program has completed the stage of activities in the field. The whole series of devotional activities have been completed and received a fairly high appreciation from the target community group. Even the target community wants regular follow-up activities as a form of mentoring and synergy between educational institutions and the community. Considering the theme of devotion raised in accordance with the reality of the problems faced by the people of Lobang Village, Limpung Subdistrict, Batang Regency.

This community service activity is a scientific application from the research team in addressing the problems that exist in the community of Lobang Village, Limbung District, Batang Regency. This community service activity is carried out with the aim of improving insights and knowledge on production management issues as well as catfish cultivation marketing networks to members of farmer groups, improving community empowerment through the formation of communities or business groups consisting of members of farmer groups, and encouraging the interest of members of the Farmer Group of Lobang Village to start catfish farming businesses to increase the supply of catfish production in Batang Regency. Based on the background of research and study, the research team tried to provide a creative solution to the problems faced by farmer groups that are still stagnant only developing in the agricultural sector. The knowledge of the research team in this case can be presented through Focus Group Discussion (FGD) as well as catfish cultivation training, this can be presented in the village of Lobang District Limbung Batang Regency.

Farmer group of Lobang Village Limbung District Batang district at first experienced a lot of trouble in running its business. The problems, among others, have not been optimal in the empowerment of community groups and the utilization of land potential and Human Resources is still limited. These problems arise because so far most of the population has a livelihood as farmers. There are farmer groups but it is still limited to agricultural activities only. Therefore, KUBE is needed in order to increase the capacity of empowerment and welfare of farmers. Catfish cultivation is considered suitable because it is easy in enlargement and marketing. Therefore, the strengthening of KUBE by diversifying catfish cultivation is expected to be able to increase the capacity of KUBE to be formed. This service activity is carried out in order to provide solutions in solving problems 
faced by the people of Lobang Village, Limbung District, Batang Regency.

In this activity partners will be given Focus Group Discussion (FGD) using participatory approach. This approach is used so that group members understand about the 3 principles of business groups to be formed, namely openness, trust, and togetherness. And furthermore, catfish cultivation training where this activity begins by gathering the community, especially farmer groups to be given understanding or given counseling on how to cultivate catfish. Then carried out training and practice of the cultivation process. After that will be conducted counseling again on how to manage the business and marketing of the results of the business. From this community service is expected to improve the welfare of the community of Lobang Village Limbung District Batang Regency.

In the results of the FGD it was determined that the farmer group that would keep the catfish was handed over to the chairman of RT 2 and five people who became the first mobilizers of the group. The division of his task is to do pickets to take care of catfish in turns. The basis of determining the members of the group is the one whose residence is close to the catfish pond.

Figure 1.

Tarpaulin Pond Making Process

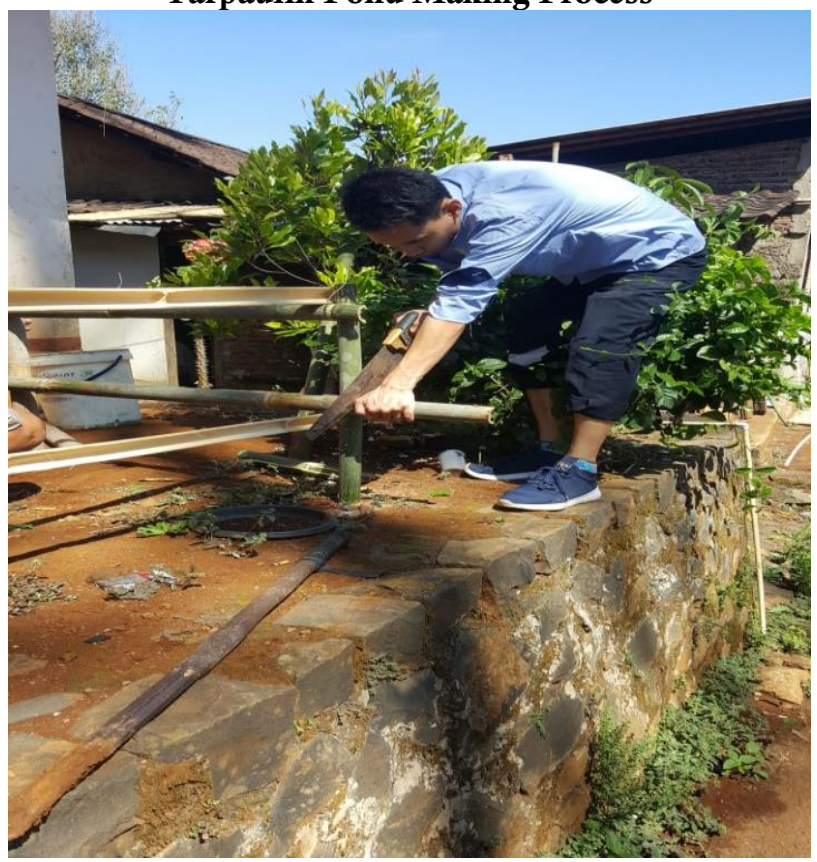

After the FGD activities are implemented, the next stage is technical activities. In this case is the creation of catfish ponds, the establishment of a joint breeder group organization and training in catfish breeding. Catfish ponds are built using tarpaulin material. This material was chosen because it is weatherproof, easy to maintain, as well as cheap in manufacturing. The tarpaulin pond is made with a size of $3 \times 4$ meters and holds 1500 catfish. The process of making ponds and spreading fish was carried out on
September 4, 2020. The catfish pond is located next to the chairman's house RT and adjacent to the village head office. The location is set there due to safety and ease of access to clean water and maintenance.

Before the catfish pond is stocked with fish, the group members are first given information on how to spread, feed until the harvest age. Then perform the process of draining water and sorting the fish.

Figure 2.

Ready-made catfish pond

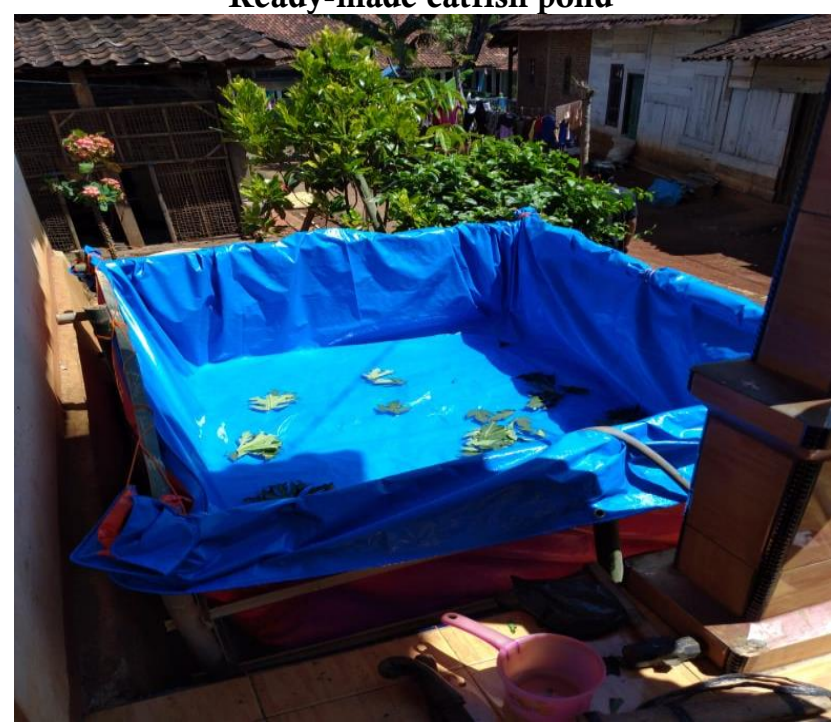

At this time the cultivation program has been carried out well, the results of catfish cultivation have been large and can be harvested immediately. After harvesting the catfish as for the sustainability plan is to buy catfish seedlings and add more catfish ponds with the proceeds of the catfish sales revenue. This is very helpful to the surrounding community in an effort to improve the welfare of the people of Lobang Village, Limbung District, Batang Regency. Based on the results of an online evaluation on October 23, 2020 it is known that catfish in the pond is developing well. The community also performs scheduling to care for catfish and the treatment process is carried out according to the instructions during the training.

Planned 3 months from the time of distribution or December 4, 2020 catfish can already be harvested. Hopefully, these well-developed catfish seedlings will grow. Provide better crops with the target of creating one more pond and recruiting 5 more people as new group members. In addition, other communities are also expected to be encouraged to cultivate catfish as an alternative to family nutrition fulfillment and it is possible to become an additional source of income

\section{CONCLUSION}

Based on the results of this program it is known that the training program and assistance in providing catfish packages and ponds are felt to have been quite successfully implemented. In addition, cultivated catfish are already developed and ready to be harvested to 
support food security and the family economy. At this time the cultivation program has been carried out well, at this time the results of catfish cultivation are large and can be harvested immediately. After harvesting the catfish as for the sustainability plan is to buy catfish seedlings and add more catfish ponds with the proceeds of the catfish sales revenue. This is very helpful to the surrounding community in an effort to improve the welfare of the people of Lobang Village, Limbung District, Batang Regency.

\section{REFERENCES}

Adimihardja, K., \& Hikmat, I. H. (2003). Participatory Research Appraisal: Dalam Pelaksanaan Pengabdian Kepada Masyarakat. Humaniora.

Widia, S. Affandi, Agus. 2014. Modul Participatory Action Research (PAR); Untuk Pengorganisasian Mayarakat (Community Organizing). Surabaya: LPPM.

Chambers, R. (1996). PRA: Participatory Rural Appraisal, Memahami Desa Secara Partisipatif. Walter de Gruyter.

Dimyati, M. (2006). Belajar dan pembelajaran. Jakarta: Rineka Cipta.

Lauer, R. H. (1993). Perspektif tentang perubahan sosial. Jakarta: Rineka Cipta.

Notoatmodjo, S. (2009). Pengembangan SDM. Edisi Revisi. Jakarta: Bineka Cupta.

Roesmidi, H., \& Risyanti, R. (2006). Pemberdayaan Masyarakat (Cetakan 2). Sumedang: Penerbit Alqaprint Jatinangor.)

Sumodiningrat, G. (1998). Membangun perekonomian rakyat. Pustaka Pelajar. 